\section{NON-ALTITUDE-RELATED SPLENIC INFARCTION IN A PATIENT WITH SICKLE CELL TRAIT}

Splenic infarction is a well-documented complication of sickle cell anemia, sickle cell-hemoglobin $\mathrm{C}$ disease, and sickle cell- $\beta$-thalassemia disease. Many of these cases have been associated with exposure to high altitudes [1]. There have also been reported cases of highaltitude-related splenic infarction in persons with sickle cell trait (hemoglobin AS), usually considered to be a benign hemoglobinopathy $[1,2]$. Splenic infarction not related to high-altitude exposure in persons with sickle cell trait has been reported five times previously [2$6]$. We report an additional case of non-altitude-related splenic infarction in a patient with sickle cell trait, and review the literature in an attempt to better understand this disorder.

An obese 27-year-old man of Middle Eastern descent was in his usual state of health until July 1987 , when he was awakened by the abrupt onset of nausea and vomiting. This was followed by the development of severe left upper quadrant abdominal pain that radiated to the back. The pain was nonpositional, did not vary with respiration, increased postprandially, and was associated with mild dyspnea. He was treated with ampicillin but had no improvement. Because of increasing pain, he was hospitalized with a temperature of $38.3^{\circ} \mathrm{C}$, hemoglobin level of $8.5 \mathrm{mmol} / \mathrm{L}$, hematocrit of 0.39 , total leukocyte count of $24.5 \times 10^{9} / \mathrm{L}$ with normal differential, and platelet count of $322 \times 10^{9} / \mathrm{L}$. Serum chemistries, serum lipase, rheumatoid factor, antinuclear antibody, cold agglutinins, antimitochondrial antibody, and Monospot ${ }^{\boxplus}$ test result were normal. Abnormal findings on laboratory studies included the following: erythrocyte sedimentation rate $42 \mathrm{~mm} /$ hour, uric acid 0.6 $\mathrm{mmol} / \mathrm{L}$, and lactate dehydrogenase $3,317 \mathrm{nmol} / \mathrm{second} / \mathrm{L}$ with increased $\mathrm{LDH}_{5}$ fraction. Past medical and family histories were noncontributory.

Chest radiography revealed a triangular density that was believed to be a combination of infiltrate and atelectasis/consolidation, with a small left pleural effusion. Roomair arterial blood gas studies revealed a $\mathrm{pH}$ of 7.45, oxygen tension of $73 \mathrm{~mm} \mathrm{Hg}$, carbon dioxide tension of $37 \mathrm{~mm} \mathrm{Hg}$, and bicarbonate level of $25 \mathrm{mEq} / \mathrm{L}$. Thoracentesis revealed a total leukocyte count of $8.99 \times 10^{9} / \mathrm{L}$ with $93 \%$ polymorphonuclear leukocytes and $2 \%$ monocytes, glucose greater than 33.6 $\mathrm{mmol} / \mathrm{L}$, lactate dehydrogenase $303,000 \mathrm{nmol} / \mathrm{second} / \mathrm{L}$, protein $180 \mathrm{~g} / \mathrm{L}$, negative bacterial and acid-fast bacilli smears and cultures, and negative results of cytologic study. Evaluation of Hemoccult-positive stool included a barium enema, results of which were normal.

Because of persistent left upper quadrant pain, further studies were performed. A retrograde pyelogram, intravenous pyelogram, cystoscopy, and renal ultrasound failed to explain the etiology of his pain. An indium scan revealed increased activity in the right lung and within the midline anterior chest in a linear pattern; there was no activity within the spleen. Findings on a liver/spleen scan were significant for nonvisualization of the spleen.

The patient's platelet count gradually increased to $1,100 \times 10^{9} /$ L on the 10th hospital day, with a persistent mild anemia and a persistent leukocytosis of $24.0 \times 10^{9} /$ L. His serum lactate dehydrogenase level also increased to 5,267 $\mathrm{nmol} / \mathrm{second} / \mathrm{L}$. Because of persistent thrombocytosis of greater than $1 \times 10^{12}\left(1,440 \times 10^{9} / \mathrm{L}\right)$ and the leukocytosis, the patient was transferred to the University of Michigan Medical Center (UMMC) for further evaluation.

Upon admission to UMMC, physical examination revealed the patient to be in no apparent distress with a temperature of $37.6^{\circ} \mathrm{C}$. His lung fields were clear. Cardiac examination demonstrated no murmurs. Abdominal examination revealed a soft, obese abdomen without organomegaly or masses and normal active bowel sounds. There was no clinical evidence for the presence of obesity-associated hypoventilation of pulmonary embolus. Hemoglobin was $8.2 \mathrm{mmol} /$ $\mathrm{L}$, hematocrit was 0.40 , total leukocyte count was $25.7 \times 10^{\%} / \mathrm{L}$ with
$55 \%$ segmented forms, $3 \%$ bands, $23 \%$ lymphocytes, and $19 \%$ monocytes, and platelet count was 1,000 $\times 10^{9} / \mathrm{L}$. Findings on other laboratory studies were unremarkable, except for aspartate aminotransferase $667 \mathrm{nmol} / \mathrm{second} / \mathrm{L}$, alanine aminotransferase $700 \mathrm{nmol} / \mathrm{sec}$ ond/L, lactate dehydrogenase $4,833 \mathrm{nmol} / \mathrm{second} / \mathrm{L}$, and 24-hour urine protein excretion $0.72 \mathrm{~g}$. Peripheral blood smear revealed predominantly normal red blood cell morphology, numerous platelets, normal white blood cells without toxic granulations, and the presence of several metamyelocytes. Reticulocyte count was 0.092 . Hemoglobin electrophoresis demonstrated the presence of sickle cell trait with 0.577 hemoglobin $\mathrm{A}_{1}$, 0.030 hemoglobin $A_{2}$, and 0.393 hemoglobin $\mathrm{S}$. No anomalous $\mathrm{mi}-$ gration of hemoglobin $A_{1}$ was noted.

Chest radiography revealed a left-sided pleural effusion and left lower lobe atelectasis. Ultrasound showed an irregular fluid collection in the spleen that displaced most of the residual splenic tissue medially, consistent with an intrasplenic hematoma or splenic infarction. Bone marrow examination revealed a hypercellular marrow with all cell lines present. Cytogenetic study demonstrated a normal $46, \mathrm{XY}$ chromosome pattern.

The patient's elevated white blood cell and platelet counts gradually returned to normal over the following several weeks without any further treatment. The patient's recovery was complete except for an episode of acute tophaceous gout that occurred nine days after discharge and was treated with allopurinol, which resulted in resolution of symptoms.

This is only the sixth known case of non-altitude-related splenic infarction in an individual with sickle cell trait. Review of this case and the previously reported cases reveals no single assessable variable that defines this group of patients. The patients included four males and two females, ranging from nine to 58 years of age. Two of the patients were black, two were of Middle Eastern descent, one was white of Sicilian descent, and one was Mexican. Two of the patients apparently had splenomegaly and 
one was reported to have concurrent hepatomegaly. The reported percentage of hemoglobin $\mathrm{S}$ present, in the four cases in which it was documented, ranged from 0.31 to 0.42 . The distribution of red cell hemoglobin between hemoglobin $\mathrm{S}$ and hemoglobin $\mathrm{A}$ in persons with sickle cell trait has been reported to range from 0.25 to 0.40 for hemoglobin $\mathrm{S}$ and 0.55 to 0.75 for hemoglobin $A[2]$. Five of the six patients presented with abdominal pain in the left upper quadrant, and the presenting hemoglobin levels ranged from $3.4 \mathrm{mmol} / \mathrm{L}$ to 9.0 $\mathrm{mmol} / \mathrm{L}$. Other parameters were not consistently reported in these cases to allow comparisons or conclusions to be made. Pleural effusions (particularly left-sided) and left lower lobe pulmonary infiltrates, as in our patient, have been described in patients with splenic infarctions $[1,3]$.

The treatment of the reported patients with sickle cell trait and splenic infarction has relied primarily on supportive care. All of the reported cases, including ours, appear to have done well with such measures. The role of splenectomy in these patients remains unclear. At best, there does not appear to be any clear indication for splenectomy in these patients, except possibly for patients who experience recurrent episodes of splenic infarction and for those with intractable persistent pain.

Our case, and the five related cases reviewed, suggest that patients presenting with findings consistent with splenic infarction should have sickle cell trait considered as a predisposing factor in their differential diagnosis, even in the absence of high-altitude exposure. Sickle cell trait appears to be a relatively benign cause of splenic infarction. Treatment should be supportive and directed toward correcting any additional predisposing conditions or subsequent complications. These cases do not contradict the findings that life expectancy is normal in persons with sickle cell trait, as none of the reported patients with non-altituderelated splenic infarctions developed significant sequelae.

SCOTT D. GITLIN, M.D. CRAIG B. THOMPSON, M.D. The Howard Hughes Medical Institute

University of Michigan Medical Center

Ann Arbor, Michigan 48109-0650
1. Lane PA, Githens JH: Splenic syndrome at mounain altitudes in sickle cell trait. JAMA 1985; 253: 2251-2254

2. Magnuson TR, Hunter SW, Bonnabeau RC Jr: Multiple vascular infarction: a manifestation of sickle cell trait in the absence of hypoxia. Minn Med 1980; 63: 381-383.

3. O'Brien RT, Pearson HA, Godley JA, Spencer RP: Splenic infarct and sickle-(cell) trait. N Engl J Med 1972: 287: 720.

4. King DT, Lindstrom RR, State $D$, Hirose FM Schwartz A: Unusual cause of acute abdomen: sickle cell trait and nonhypoxic splenic infarction. JAMA 1977; 238: 2173-2174.

5. Buch P, Prichep R, Rosner F: Sickle cell trait with splenic infarcts. NY State J Med 1982; 82: 1087 1088.

6. Goel RG, Qureshi MA, Abdali MS: Hemoglobin sickle gene in Afghanistan. Indian Pediatr 1982; 19: 106

Submitted June 27, 1989, and accepted August 8

1989

\section{PENTAMIDINE-INDUCED SEVERE HYPERKALEMIA}

Hyperkalemia is an important potential complication of pentamidine isethionate treatment. The Physicians' Desk Reference lists it as moderate, i.e., "non-life-threatening reaction," occurring in only $0.7 \%$ of patients treated, and despite the vast current literature on the subject, we found documentation of this reaction in only two sources $[1,2]$. We now report a case of life-threatening hyperkalemia occurring in a patient treated for presumed Pneumocystis carinii pneumonia (PCP).

A 38-year-old homosexual black man with a history of intravenous drug abuse presented with fever, chills, and drenching night sweats for two weeks. His temperature was $39^{\circ} \mathrm{C}$, pulse was $92 /$ minute and regular, and respirations were $24 / \mathrm{min}$ ute. Generalized lymphadenopathy, bibasilar inspiratory rales, and hepatosplenomegaly were apparent on physical examination. Chest radiography revealed bilateral interstitial infiltrates, and resting arterial blood gas studies showed a $\mathrm{pH}$ of 7.51, carbon dioxide tension of $25 \mathrm{~mm} \mathrm{Hg}$, and oxygen tension of $62 \mathrm{~mm} \mathrm{Hg}$. Gallium scan showed minimal activity at both lung bases, but bronchoscopy failed to identify an etiology for his pneumonia.

Treatment for presumed PCP was initiated with intramuscular pentamidine at the recommended $4 \mathrm{mg} / \mathrm{kg} /$ day dose $(220 \mathrm{mg}$ in our patient). This resulted in prompt improvement of his dyspnea, fever, and sweats. During treatment, a modest deterioration in renal function was observed as the creatinine level increased from $0.9 \mathrm{mg} / \mathrm{dL}$ to
$1.8 \mathrm{mg} / \mathrm{dL}$ and blood urea nitrogen (BUN) increased from $13 \mathrm{mg} / \mathrm{dL}$ to $39 \mathrm{mg} / \mathrm{dL}$ over an eight-day period. During this time, the serum potassium level rose from a pretreatment value of $4.1 \mathrm{mEq} / \mathrm{L}$ to 5.5 $\mathrm{mEq} / \mathrm{L}$ by Day $4,5.7 \mathrm{mEq} / \mathrm{L}$ by Day 7 , and $7.6 \mathrm{mEq} / \mathrm{L}$ on Day 8 , associated with peaked $\mathrm{T}$ waves and QRS complex widening.

Treatment with pentamidine was stopped, electrocardiographic changes resolved, and serum potassium level fell after emergent treatment with intravenous calcium gluconate, insulin, dextrose, and oral sodium polystyrene sulfonate (Kayexalate $\left.{ }^{(}\right)$. A second gradual increase in potassium to $6.5 \mathrm{mEq} / \mathrm{L}$ occurred over the five days following discontinuation of pentamidine, and this too necessitated treatment with oral Kayexalate. Upon cessation of pentamidine, treatment with trimethoprim-sulfamethoxazole was started and continued for six days, so that the patient received a total of 14 days of antibiotic treatment. After three weeks of hospitalization, he was discharged in much improved condition with resolution of radiographic findings and hypoxia. The potassium level remained within normal limits (less than $4.9 \mathrm{mEq}$ / L) for five days prior to discharge without specific therapy. Weeks later, results of serologic testing in the patient returned positive for human immunodeficiency virus infection.

We could find no obvious explanation for our patient's hyperkalemia. With the exception of acetaminophen, pentamidine was the only medication he received before the development of maximal hyperkalemia. Laboratory evidence of hemolysis was lacking, with a reticulocyte index of $1 \%$, stable hematocrit, bilirubin, and lactic dehydrogenase (LDH), and a normal serum haptoglobin level. The patient never complained of pain at the intramuscular injection site nor was there was any sign of local tissue necrosis or abscess, or laboratory evidence of acidosis, and rhabdomyolysis seemed unlikely with a stable LDH and aspartate aminotransferase (SGOT) during hospitalization.

Renal insufficiency is the most frequent systemic side effect of pentamidine, seen in approximately $25 \%$ of patients; it is usually mild and reversible and its mechanism is unknown $[1,3]$. The pharmacoki- 